\title{
Differential Settlement at Bridge Approaches' in Bangladesh
}

\author{
Md. Firoz Mahmood Ovi, Md. Ridwan Bin Alam, Abontee Barua, S. Halder, and Md. Waliur Rahman
}

\begin{abstract}
Differential settlement at the roadway/bridge interface typically results in an abrupt grade change, causing driver discomfort, impairing driver safety, and exerting a potentially excessive impact traffic loading on the abutment. Bridge approach slabs are used to keep the effects of this differential settlement within tolerable limits. In many cases, the final magnitude of settlement exceeds the working range of an approach slab, necessitating costly roadway and slab repairs. The potential causes for this problem purely site specific. Hence this settlement problem may not have a unique solution. The purpose of this study was to investigate differential settlement at bridge approaches and give possible solutions of this problem using available materials and manpower in the context of Bangladesh. In most cases the differential settlement occurs at mid portion. This can be said to be the most critical location.
\end{abstract}

Index Terms-Bangladesh, bridge approach slab, differential settlement, mitigation techniques.

\section{INTRODUCTION}

In the case of most bridge, the approaches are often considered to be a minor element of the project in terms of cost as well as the engineering challenges involved in design and construction. A proactive attempt to employ sound engineering principles for the design, specification and construction of approaches is often lacking. From the point of view of the user, a satisfactory approach to the structure is also very important and hence it is very essential that all relevant aspects of the approaches are carefully evaluated and suitable remedial measures designed to ensure the safety and serviceability of the approach throughout the design life of the structure.

Approach maintenance problems, manifested by a characteristic bump felt when driving onto or away from a bridge. Although this problem is commonly recognized and its causes are clearly identified, no unified set of engineering solutions has emerged; primarily because of the number and complexity of the factors involved. Very seldom can settlement at bridge approaches be traced to a single cause. Typically, settlement reflects an aggregate effect of subsoil conditions, materials, construction techniques, drainage provisions, and quality control methods.

The objective of this study is to identify the probable causes of differential settlement at bridge approaches, factors influencing development of settlement and probable solution that reduce or eliminate development of settlement at approach. A field study was also conducted to determine the

Manuscript received November 9, 2013; revised February 12, 2014.

The authors are with the Department of Civil Engineering, Ahsanullah University of Science and Technology, Bangladesh (e-mail: romudhaka@yahoo.com). extent and probable causes of settlement development at approach in various bridge sites.

\section{Mechanisms CAUSING BRIDGE APPROACH SETTLEMENT}

Wahls (1990) [1] as well as many researchers studied cause of settlement at bridge approaches' and identified the causes of bridge approach settlement [2]-[7], which have been grouped into five major categories:

- Poor Performance of Approach Pavements

- Types of Bridge Abutments and Foundation Support

- Deformation of Embankment Fill

- Deformation of Foundation Soil

- Poor Drainage

The summary of these major causes are presented in Table I.

TABLE I: SUMMARY OF CAUSES OF BRIDGE APPROACH SETTLEMENT

\begin{tabular}{|c|c|}
\hline Category & Causes \\
\hline $\begin{array}{l}\text { 1.Poor } \\
\text { Performance of } \\
\text { Approach Pavement }\end{array}$ & $\begin{array}{l}\text { A. Deformation in Flexible Pavement: Rutting, } \\
\text { shoving or cracking. } \\
\text { B. Failures in Concrete Pavements: transverse } \\
\text { cracking, joint faulting, corner breaks, or } \\
\text { blowup. } \\
\text { C. Improper placement of roadway grades. }\end{array}$ \\
\hline $\begin{array}{l}\text { 2.Type of Bridge } \\
\text { Abutments and } \\
\text { Foundation Support }\end{array}$ & $\begin{array}{l}\text { A. Lack of maintenance of expansion joints of } \\
\text { Non-Integral Abutments causing temperature } \\
\text { induced stresses on bridge abutment } \\
\text { B. Improper Abutment or Wing wall Design }\end{array}$ \\
\hline $\begin{array}{l}\text { 3. Vertical and } \\
\text { Lateral Deformation } \\
\text { of Backfill }\end{array}$ & $\begin{array}{l}\text { A. Inadequate compaction of backfill due to } \\
\text { limited space, improper } \\
\text { construction equipment, contractor care, soil } \\
\text { type, and/or lift thickness } \\
\text { B. Post-construction consolidation of cohesive } \\
\text { soils due to the } \\
\text { embankment self-weight, traffic loads, and } \\
\text { weight of asphalt overlays } \\
\text { C. Bearing capacity failure of sleeper slab } \\
\text { footing under approach slabs }\end{array}$ \\
\hline $\begin{array}{l}\text { 4.Vertical and } \\
\text { Lateral Deformation } \\
\text { of } \\
\text { Foundation Soil }\end{array}$ & $\begin{array}{l}\text { A. Lateral squeeze of weak foundation soils due } \\
\text { to increase vertical stresses } \\
\text { B. Consolidation settlement of silt, clay and } \\
\text { organic soils due to increased effective stress }\end{array}$ \\
\hline 5. Poor Drainage & $\begin{array}{l}\text { A. Instability of slopes at the abutment from rise } \\
\text { in water level } \\
\text { B. Increase in hydrostatic pressure behind } \\
\text { abutment }\end{array}$ \\
\hline
\end{tabular}

\section{Methodology}

The survey of the bridge approaches have been measured by using a measuring tape, chalk, rope and plastic/steel ruler (shown in Fig. 1) the measurement was done. The differential settlements at bridge approaches have been measured in two phases. At first phase, 20 points have been identified on the 
bridge approaches' for measuring the settlements and at the second phase the settlements have been measured at those points. At first the joint between the bridge approach and the bridge was identified. After that the width of the joint, which was measured with a measuring tape has been divided into four parts that consists of 5 points. At those 5 points 5 lines (A, B, C, D and E) of 8 feet length each, have been imagined which were perpendicular to the width of the joint.

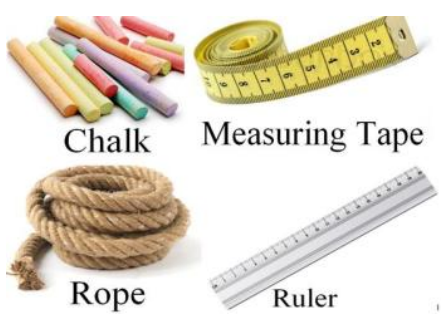

Fig. 1. Equipment used for measuring differential settlement.

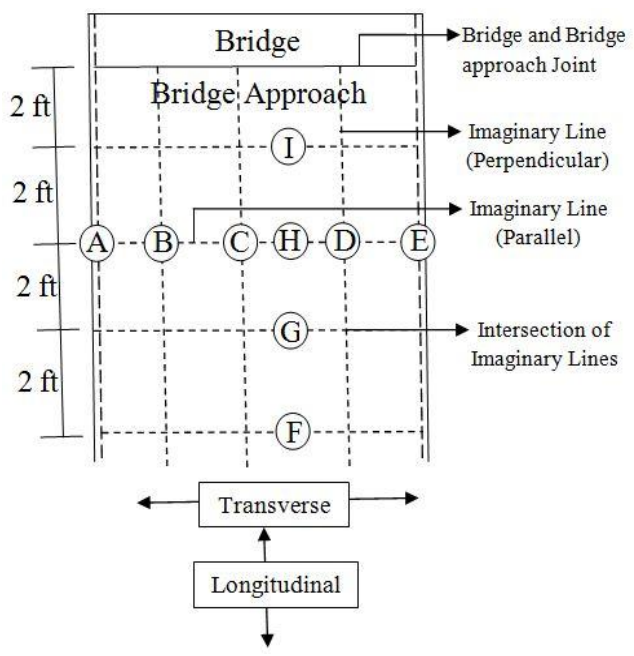

Fig. 2. Imaginary points for measuring differential settlement at bridge approach.

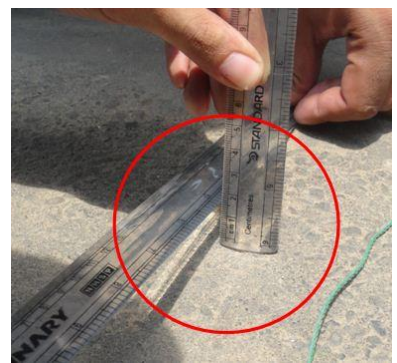

Fig. 3. Measurement of the settlement between the bridge and existing roadway level.

Again 4 more lines (F, G, H and I) have been imagined at 2 feet, 4 feet, 6 feet and 8 feet distant respectively from the joint which were parallel to the joint. These perpendicular and parallel imaginary lines intersected themselves at 20 different points and they were marked with chalk. These were the points where settlements have been measured (shown in Fig. 2 ). A rope of 8 feet has been used, of which one end was fixed at the joint and the other end was hold straight at the same horizontal level of the joint. It was possible to measure the settlement of points at 2 feet, 4 feet, 6 feet and 8 feet distance of the imaginary lines in context of the rope which was kept horizontally with the existing roadway level. The difference between the elevation of rope and the road surface is the settlement measured for that particular point. The measuring technique is illustrated in Fig. 3.

\section{DATA ANAlysis OF FIELD TEST Sites}

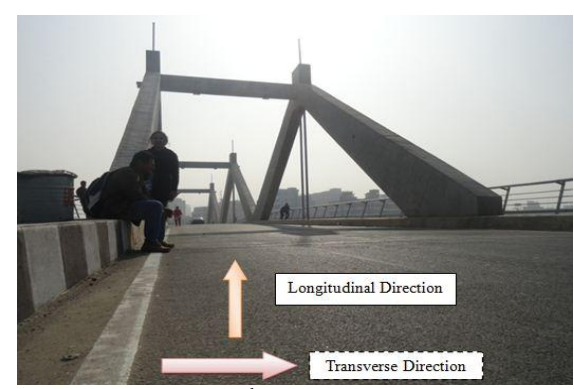

Fig. 4. Hatirjheel $4^{\text {th }}$ bridge,dhaka,Bangladesh.

TABLE II: DATA OF SURVEY SETTLEMENT IN LONGITUDINAL DIRECTION OF HATIRJHEEL $4{ }^{\mathrm{TH}}$ BRIDGE, DHAKA, BANGLADESH

\begin{tabular}{|c|c|c|c|c|c|}
\hline \multirow{2}{*}{$\begin{array}{c}\text { Distance } \\
(\mathrm{ft})\end{array}$} & \multicolumn{5}{|c|}{ Settlement(mm) } \\
\cline { 2 - 6 } & $\mathrm{A}$ & $\mathrm{B}$ & $\mathrm{C}$ & $\mathrm{D}$ & $\mathrm{E}$ \\
\hline 2 & 20 & 15 & 20 & 20 & 23 \\
\hline 4 & 28 & 25 & 33 & 25 & 28 \\
\hline 6 & 32 & 30 & 40 & 30 & 32 \\
\hline 8 & 41 & 32 & 42 & 43 & 35 \\
\hline
\end{tabular}

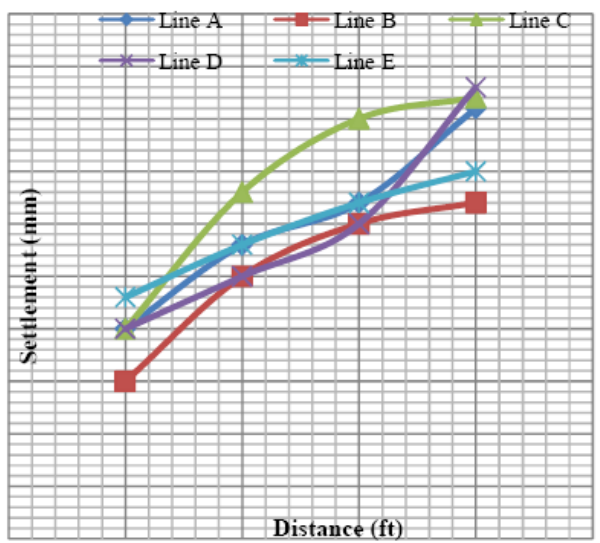

Fig. 5. Distance vs. settlement graph (hatirjheel $4^{\text {th }}$ bridge, dhaka, bangladesh- longitudinal)

TABLE III: DATA OF SURVEY SETTLEMENT IN TRANSVERSE DiRECTION OF HATIRJHEEL $4^{\mathrm{TH}}$ BRIDGE, DHAKA, BANGLADESH

\begin{tabular}{|c|c|c|c|c|}
\hline \multirow{2}{*}{$\begin{array}{c}\text { Distance } \\
(\mathrm{ft})\end{array}$} & \multicolumn{4}{|c|}{ Settlement(mm) } \\
\cline { 2 - 5 } & $\mathrm{F}$ & $\mathrm{G}$ & $\mathrm{H}$ & $\mathrm{I}$ \\
\hline 0 & 20 & 28 & 32 & 41 \\
\hline 6 & 15 & 25 & 30 & 32 \\
\hline 12 & 20 & 33 & 40 & 42 \\
\hline 18 & 20 & 25 & 30 & 43 \\
\hline 24 & 23 & 28 & 32 & 35 \\
\hline
\end{tabular}

Visual inspection carried out at Hatirjheel $4^{\text {th }}$ Bridge, Dhaka, Bangladesh (shown in Fig. 4) indicated differential settlements was 1.328 inches at the interface between the approach fills and bridge in longitudinal direction (data used are given in Table II) and 1.52 inches in transverse direction (data used are given in Table III). The Distance vs. Settlement Graph longitudinal is shown in Fig. 5 and The Distance vs. Settlement Graph transverse is shown in Fig. 6.The survey indicated differential settlement of about 0.6 to 1.7 inches near abutments (within 8 feet) in longitudinal direction. The transition slope (differential settlement divided by approach length) was calculated to be about 0.157 to 0.453 inches per foot for the North abutment of Hatirjheel Bridge, Dhaka, Bangladesh. 


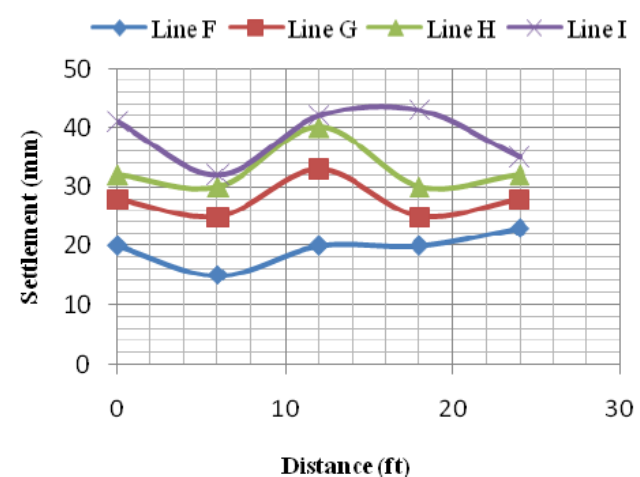

Fig. 6. Distance vs. settlement graph (hatirjheel $4^{\text {th }}$ bridge, dhaka, bangladesh - transverse).

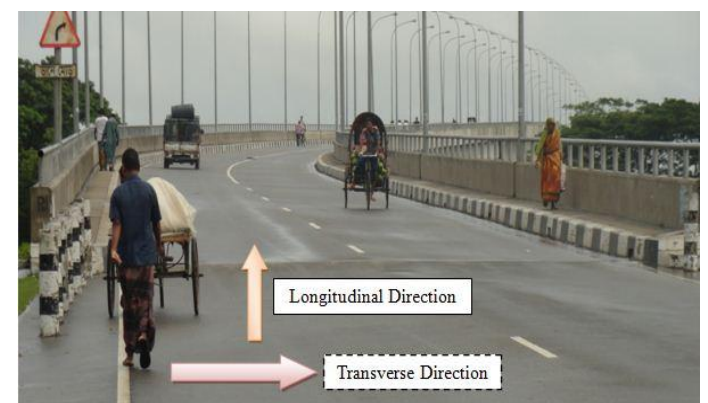

Fig. 7. Shaheed abdur rab serniabat bridge, barishal, bangladesh- east abutment.

TABLE IV: DATA OF SURVEY SETTLEMENT IN LONGITUDINAL DiRECTION of SHAHEEd Abdur RAB SERNiABAT BRIDGE, BARISHAL, BANGLADESHEAST ABUTMENT

\begin{tabular}{|c|c|c|c|c|c|}
\hline \multirow{2}{*}{$\begin{array}{c}\text { Distance } \\
\text { (ft) }\end{array}$} & \multicolumn{5}{|c|}{ Settlement(mm) } \\
\cline { 2 - 6 } & A & B & C & D & E \\
\hline 2 & 20 & 10 & 16 & 15 & 14 \\
\hline 4 & 35 & 12 & 14 & 30 & 14 \\
\hline 6 & 37.5 & 13.5 & 20 & 31 & 21 \\
\hline 8 & 40 & 15 & 26 & 32 & 28 \\
\hline
\end{tabular}

TABLE V: DATA OF SURVEY SETTLEMENT IN TRANSVERSE DIRECTION OF ShaHEed AbDUR Rab SERniabat BRIDGe, Barishal, BANGLADESH - EAST ABUTMENT

\begin{tabular}{|c|c|c|c|c|}
\hline \multirow{2}{*}{$\begin{array}{c}\text { Distance } \\
(\mathrm{ft})\end{array}$} & \multicolumn{4}{|c|}{ Settlement(mm) } \\
\cline { 2 - 5 } & $\mathrm{F}$ & $\mathrm{G}$ & $\mathrm{H}$ & $\mathrm{I}$ \\
\hline 0 & 20 & 35 & 37.5 & 40 \\
\hline 6 & 10 & 12 & 13.5 & 15 \\
\hline 12 & 16 & 14 & 20 & 26 \\
\hline 18 & 15 & 30 & 31 & 32 \\
\hline 24 & 14 & 14 & 21 & 28 \\
\hline
\end{tabular}

Visual inspection carried out at Shaheed Abdur Rab Serniabat Bridge, East Abutment, Barishal, Bangladesh (shown in Fig. 7) indicated differential settlements was 1.304 inches in longitudinal direction(data used are given in Table IV) and 1.110 inches in transverse direction(data used are given in Table V). The Distance vs. Settlement Graph longitudinal is shown in Fig. 8 and The Distance vs. Settlement Graph transverse is shown in Fig. 9. The survey indicated differential settlement of about 0.394 to 1.575 inches near abutments (within 8 feet) in longitudinal direction. The transition slope (differential settlement divided by approach length) was calculated to be about 0.074 to 0.394 inches per foot for the east abutment of Shaheed Abdur Rab Serniabat Bridge, East Abutment, Barishal, Bangladesh.

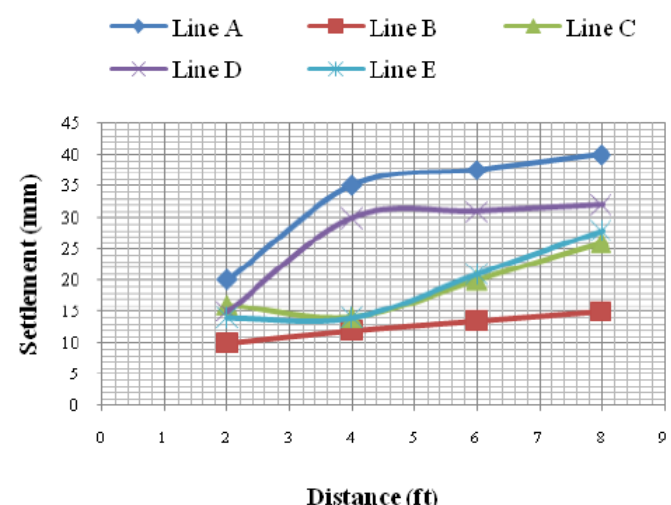

Fig. 8. Distance vs. settlement graph (shaheed abdur rab serniabat bridge, barishal, bangladesh - east abutment, longitudinal).

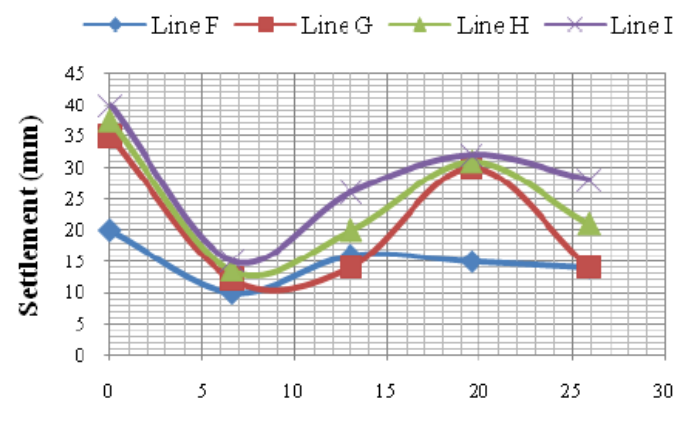

Distance (ft)

Fig. 9. Distance vs. settlement graph (shaheed abdur rab serniabat bridge, barishal, bangladesh- east abutment, transverse.)

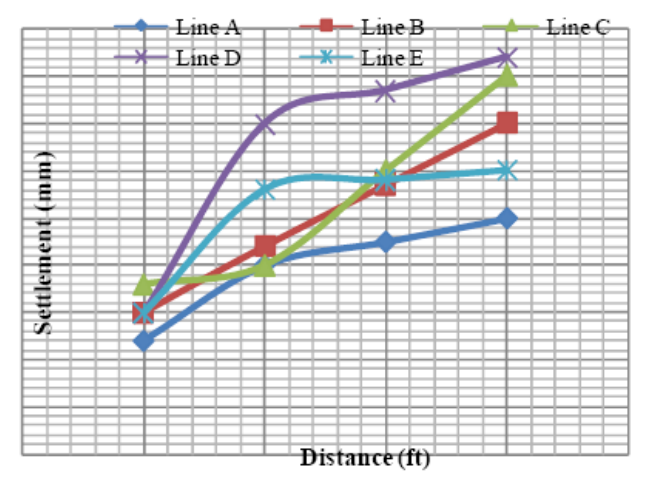

Fig. 10. Distance vs. settlement graph (shaheed abdur rab serniabat bridge, barishal, bangladesh - west abutment, longitudinal).

Visual inspection carried out at Shaheed Abdur Rab Serniabat Bridge, West Abutment, Barishal, Bangladesh indicated differential settlement was 1.284 inches in longitudinal direction(data used are given in Table VI) and 1.354 inches in transverse direction(data used are given in Table VII). The Distance vs. Settlement Graph longitudinal is shown in Fig. 10 and The Distance vs. Settlement Graph transverse is shown in Fig. 11.The survey indicated differential settlement of about 0.472 to 1.654 inches near abutments (within 8 feet) in longitudinal direction. The transition slope (differential settlement divided by approach length) was calculated to be about 0.123 to 0.354 inches per foot for the west abutment of Shaheed Abdur Rab Serniabat Bridge, West Abutment, Barishal, Bangladesh.

Comparing these graphs it can be observed that, in most cases the differential settlement occurs at mid portion. This can be said to be the most critical location. Typically, the settlement at these critical locations are attributed to a multiple number of causes; however, the causes that create the greatest magnitudes of movement are typically due to 
improper compaction of backfill behind the abutment, deformation of cohesive soils within the embankment, deformation of weak foundation soils, and poor drainage of newly placed fills. In order to control or prevent some of these problems, numerous mitigation methods have been considered.

TABLE VI: DATA OF SURVEY SETTLEMENT IN LONGITUDINAL DIRECTION OF SHAHEED ABDUR RAB SERNIABAT BRIDGE, BARISHAL, BANGLADESH WEST ABUTMENT

\begin{tabular}{|c|c|c|c|c|c|}
\hline \multirow{2}{*}{$\begin{array}{c}\text { Distance } \\
(\mathrm{ft})\end{array}$} & \multicolumn{5}{|c|}{ Settlement(mm) } \\
\cline { 2 - 6 } & $\mathrm{A}$ & $\mathrm{B}$ & $\mathrm{C}$ & $\mathrm{D}$ & E \\
\hline 2 & 12 & 15 & 18 & 15 & 15 \\
\hline 4 & 20 & 22 & 20 & 35 & 28 \\
\hline 6 & 22.5 & 28.5 & 30 & 38.5 & 29 \\
\hline 8 & 25 & 35 & 40 & 42 & 30 \\
\hline
\end{tabular}

TABLE VII: DATA OF SURVEY SETTLEMENT IN TRANSVERSE DIRECTION OF SHAHEED ABDUR RAB SERNIABAT BRIDGE, BARISHAL, BANGLADESH WEST ABUTMENT

\begin{tabular}{|c|c|c|c|c|}
\hline \multirow{2}{*}{$\begin{array}{c}\text { Distance } \\
(\mathrm{ft})\end{array}$} & \multicolumn{4}{|c|}{ Settlement(mm) } \\
\cline { 2 - 5 } & $\mathrm{F}$ & $\mathrm{G}$ & $\mathrm{H}$ & $\mathrm{I}$ \\
\hline 0 & 12 & 20 & 22.5 & 25 \\
\hline 6 & 15 & 22 & 28.5 & 35 \\
\hline 12 & 18 & 20 & 30 & 40 \\
\hline 18 & 15 & 35 & 38.5 & 42 \\
\hline 24 & 15 & 28 & 29 & 30 \\
\hline
\end{tabular}

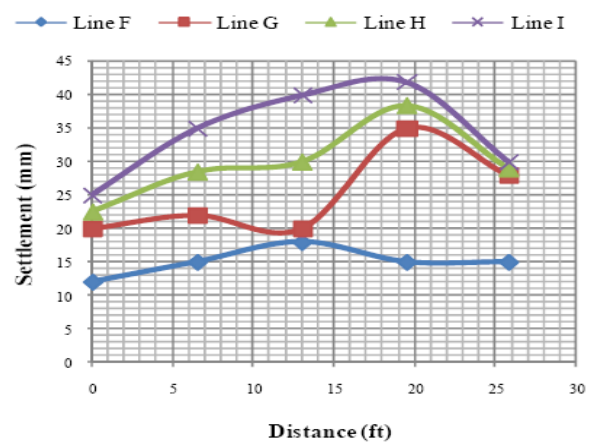

Fig. 11. Distance vs. settlement graph (shaheed abdur rab serniabat bridge, barishal, bangladesh - west abutment, transverse).

\section{CONCLUSION AND RECOMMENDED MitigATION METHODS}

TABLE VIII: SUMMARIZATIONS OF Mitigation METHODS OF BRIDGE APPROACH SETTLEMENT

\begin{tabular}{|c|c|}
\hline Cause & Mitigation Method \\
\hline \multirow{4}{*}{ Deformation of Backfill } & $\begin{array}{l}\text { More Stringent Backfill and Compaction } \\
\text { Specification }\end{array}$ \\
\hline & Lightweight Fills \\
\hline & Scheduling a Delay in Construction Work \\
\hline & Reinforced Concrete Approach Slab \\
\hline \multirow{4}{*}{$\begin{array}{l}\text { Deformation of Foundation } \\
\text { Soil }\end{array}$} & $\begin{array}{l}\text { Removal and Replacement of Weak } \\
\text { Foundation Soils }\end{array}$ \\
\hline & $\begin{array}{l}\text { Ground Improvement (mechanical or } \\
\text { chemical) }\end{array}$ \\
\hline & Surcharging \\
\hline & $\begin{array}{l}\text { Supporting Embankment on Deep } \\
\text { Foundations }\end{array}$ \\
\hline \multirow{5}{*}{ Drainage } & Flatter Side Slopes \\
\hline & Backfill and Surface Drains \\
\hline & Diverting Water away from the Abutment \\
\hline & Increasing Surface Drainage \\
\hline & Maintaining Watertight Joints \\
\hline
\end{tabular}

For this study it can be concluded that the critical place of settlement is the mid portion of the approaches. This results due to the poor lane management that exists in Bangladesh. Heavy trucks normally do not use the lanes in a manner which is normally used in developed countries. Again, the axle load limits are poorly controlled as a result excessive settlement usually occurs in bridge approaches in Bangladesh and bumps are very common. It is apparent from the literature review and data analysis carried out in this research that the three major causes of bridge approach settlement are: deformation of backfill, deformation of foundations soils, and poor drainage. The summarization of the mitigation methods of bridge approach settlement are given below at Table VIII.

\section{REFERENCES}

[1] H. E. Wahls, "NCHRP synthesis of highway practice 159: design and construction of bridge approaches," Transportation Research Board National Research Council, Washington D.C., pp. 45, 1990,

[2] J. G. Laguros, M. Zaman, and I. U. Mahmood, "Evaluation of causes of excessive settlements of pavements behind bridge abutments and their remedies - phase II.," Report No. FHWA/OK 89 (07), Oklahoma Department of Transportation, Oklahoma City, pp. 20, January 1990.

[3] R. W. James, H. Zhang, D. G. Zollinger, L. J. Thompson, R. F. Bruner and D. Xin, "Study of bridge approach roughness," Report No. FHWA/TX-91/1213-1F, Texas Department of Transportation, Austin, pp. 116, April 1995.

[4] V. R. Schaefer and J. C. Koch, "Void development under bridge approaches," Report No. SD90-03, South Dakota Department of Transportation, Pierre, pp. 147, November 1992.

[5] T. K. Stark, S. M. Olson, and J. H. Long, "Differential movement at the embankment/structure interface - mitigation and rehabilitation," Report No. IAB=H1, FY93, Illinois Department of Transportation, Springfield, 1995, pp. 297, April 1995.

[6] J. Briaud, R. W. James, and S. B. Hoffman, "NCHRP synthesis of highway practice 234: settlement of bridge approaches (The bump at the end of the bridge)," Transportation Research Board, National Reseach Council, Washington, D.C. pp. 75, 1997.

[7] G. Hearn, "Synthesis on faulted pavement at bridge abutments," Report No. CDOTDTD- 97-11, Colorado Department of Transportation, Denver, pp. 218, May 1997.
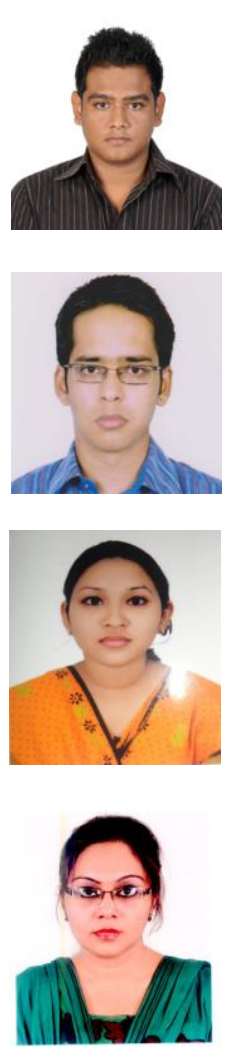

Md. Firoz Mahmood Ovi was born in Dhaka, Bangladesh on 30 May 1991. He passed his SSC examination from Monipur High School, Dhaka in 2006 and his HSC examination from Dhaka College, Dhaka in 2008. He completed his graduation in civi engineering from Ahsanullah University of Science \& Technology in 2013.

Md. Ridwan Bin Alam was born in Chittagong, Bangladesh on 23 September 1991. He passed his SSC examination from Chittagong Collegiate School, Chittagong in 2007 and his HSC examination from Notre Dame College, Dhaka in 2009. He completed his graduation in civil engineering from Ahsanullah University of Science \& Technology in 2013.

Abontee Barua was born in Chittagong, Bangladesh on 26 September 1990. She passed her SSC examination from St. Scholastica's Girls' High School, Chittagong in 2006 and her HSC examination from Govt. City College, Chittagong in 2008. She completed her graduation in civil engineering from Ahsanullah University of Science \& Technology in 2013.

Sanchari Halder was born in Barishal, Bangladesh on 6 October 1990. She passed her SSC examination from Power Development Board High School, Kushtia in 2005 and her HSC examination from Government Women's College, Barisal in 2008. She completed her graduation in civil engineering from Ahsanullah University of Science \& Technology in 2013. 
Md. Waliur Rahman has obtained BSc. in civil engineering from Bangladesh University of Engineering and Technology, Dhaka, Bangladesh in 1992. He also obtained an M.Phil in 2004 and a PhD degree in 2008 from the University of Birmingham, UK. He worked as a research engineer (Post Doc) for University of Leeds, UK.
He is a part-time faculty member of University of Asia Pacific, Ahsanullah University of Science and Technology and Military Institute of Science and Technology, Dhaka, Bangladesh. He has been working for a JICA funded Road and Bridge Project as a Project Manager for the last four years.

He published and presented 13 papers in journals and conference proceedings. 